\title{
West Nile virus activity in Latin America and the Caribbean
}

\author{
Nicholas Komar ${ }^{1}$ and Gary G. Clark ${ }^{2}$
}

Suggested citation Komar N, Clark GG. West Nile Virus activity in Latin America and the Caribbean. Rev Panam Salud Publica. 2006;19(2):112-7.

\begin{abstract}
Objectives. West Nile virus (Flavivirus: Flaviviridae; WNV) has spread rapidly throughout the Caribbean Basin since its initial detection there in 2001. This report summarizes our current knowledge of WNV transmission in tropical America.

Methods. We reviewed the published literature and consulted with key public health officials to obtain unpublished data.

Results. West Nile virus infections first appeared in human residents of the Cayman Islands and the Florida Keys in 2001, and in apparently healthy Jamaican birds sampled early in 2002. Serologic evidence of WNV infection in 2002 was detected in horses, chickens and resident free-ranging birds in Guadeloupe, the Dominican Republic, and eastern Mexico. In 2003, WNV spread in Mexico and northern Central America, and serologic evidence was detected in the Bahamas, Puerto Rico and Cuba. In 2004, the first serologic evidence of WNV activity in South American ecosystems surfaced in September-October in Colombia and Trinidad, where domestic animals circulated WNV-neutralizing antibodies.

Conclusions. The sparse reports of equine, human and avian disease in Latin America and the Caribbean is puzzling. Isolates are needed to evaluate viral attenuation or other possible explanations for reduced disease burden in tropical ecosystems.
\end{abstract}

Key words West Nile virus; Latin America; Caribbean region; arboviruses; population surveillance; flavivirus.

\section{INTRODUCTION}

Since West Nile virus (Flavivirus: Flaviviridae; WNV) first appeared in the Western Hemisphere in New York

\footnotetext{
Centers for Disease Control and Prevention, Division of Vector-Borne Infectious Diseases, PO Box 2087 Fort Collins, Colorado 80522, United States of America. Send correspondence and reprint requests to Nicholas Komar, ScD, Arbovirus Diseases Branch, Centers for Disease Control and Prevention, PO Box 2087, Fort Collins CO 80522, United States of America; telephone: (970) 2216496; fax: (970) 2216476; e-mail: nkomar@cdc.gov

2 Centers for Disease Control and Prevention, Division of Vector-Borne Infectious Diseases, 1324 Calle Cañada, San Juan 00920, Puerto Rico.
}

in 1999, it has spread rapidly across the North American continent, causing large numbers of human cases with neurologic disease and death, and even greater amounts of milder disease characterized principally by fever and rash. Horses and hundreds of species of birds also fell victim to this emerging virus (1). West Nile virus spread southward into the Caribbean Basin and Latin America as well, where its public health impact remains poorly understood and surveillance systems are unprepared to track its spread. The virus was first detected in 2001, in Jamaica and the Cayman Is- lands. In 2005 WNV activity was reported from many locations in the Caribbean Basin, Mexico, Central America and the northern rim of South America (Figure 1). In order to package our current knowledge of WNV activity and surveillance results from various locations within tropical America, we reviewed published reports and some unpublished data available from public health officials, and provide a summary below. We also comment on the significance of the surveillance findings and on the potential public health threat of WNV in tropical America. 


\section{METHODS}

We reviewed peer-reviewed publications and government reports and consulted with key public health officials within Caribbean Basin countries to obtain unpublished data.

\section{RESULTS}

\section{West Nile virus detected in 2001}

In the State of Florida (United States of America), Blackmore et al. described surveillance findings for WNV in two epidemic foci in 2001-a northern focus and a southern focus (2). The northern focus was characterized by humid temperate forests typical of the southeastern United States but unlike tropical ecosystems in Latin America. The first evidence for WNV activity here was a dead American Crow (Corvus brachyrhynchos) in June, 2001. Nine human cases of West Nile neurologic disease (WNND) were reported between July and October. Entomologic investigations near case residences in July detected WNV in three species of Culex (Culex) mosquitoes: Culex quinquefasciatus, C. nigripalpus and $C$. salinarius $(3,4)$. The first two of these species are common further south in the Caribbean Basin.

The southern epidemic focus in Florida was more typical of Caribbean Island ecology and occurred in the Florida Keys. A human case of WNND with onset in July, 2001, represented the earliest indication of WNV activity there. Two more human cases were reported with onsets in August and September. West Nile virus was isolated from dead corvids (e.g., Fish Crow, Corvus ossifragus) and Streptopelia doves (probably Streptopelia decaocto, Eurasian Collared-Dove, an introduced species that is also abundant in the Bahamas). Entomologic investigations were carried out throughout the Keys during the last quarter of 2001 (5). Infection rates were highest in Anopheles atropos (3 of 410), Deinocerites cancer (2 of 845) and Ochlerotatus taeniorhynchus (2 of 9288). This last species is a ferocious human biter, and abundant in coastal locations throughout the Caribbean Basin. About 20000 other mosquitoes tested negative.

Follow-up mosquito surveillance studies in the Florida Keys in the following two years yielded no WNV in more than 30000 mosquitoes tested in 2002 , but the virus was detected in 10 pools representing 53673 mosquitoes in 2003 (6). In 2003, infections were detected from May-September. Infected species included C. quinquefasciatus (minimum infection rate 1.7 per 1000 ), C. nigripalpus (0.9), O. taeniorhynchus (0.9), O. condolescens (0.6) and C. erraticus or declarator (0.6). No infections were detected in either $A$. atropos or $D$. cancer even though more than 5000 of each species were tested. These findings suggest that either WNV became endemic in the Florida Keys but dropped below levels of detection in 2002 , or that multiple, temporally dispersed introductions occurred, resulting in transmission activity in both 2001 and 2003.

Although the circumstances of WNV introduction into the Florida Keys are unknown, the likely explanation is that migrating birds served as dispersal hosts, seeding the virus into potential transmission foci during their southward migration in the fall of 2000. By late 2000, WNV activity was reported as far south as North Carolina in the continental United States (7). The virus had probably spread even further south at undetectable levels, to be amplified by resident birds and Culex mosquitoes during the warmer spring and early summer months of 2001. While migrating birds are a convenient explanation of WNV dispersal, other possible means of dispersion exist, such as infected mosquitoes that are accidentally transported via surface transportation or airplanes.

South of the Florida Keys, a human WNND case with no history of international travel was reported with onset on August 2, 2001, from tiny Cayman Brac (area 14 square miles [36 square kilometers], population 1200 ), in the Cayman Islands, south of Cuba (8). Assuming an incubation period of 2-15 days in people, this infection probably occurred in late July, about the same time that the first human case was infected in the Florida Keys. However, the laboratory diagnosis of this case was not announced until October 15,2001 . Laboratory tests were positive for anti-WNV IgM (indicating recent infection) and a $90 \%$ plaquereduction neutralizing antibody titer $\left(\mathrm{PRNT}_{90}\right)$ of 1:1280, compared with a $\mathrm{PRNT}_{90}$ of 1:80 and $<1: 10$ for St. Louis encephalitis virus (SLEV) and Dengue2 virus, respectively (CDC, unpublished data).

More data supporting WNV transmission activity in the Caribbean Basin in 2001 came from Jamaica, where a Smithsonian Institution-New York State Health Department research team reported 17 seropositive resident birds of 348 collected in 3 of 4 study sites, all on the western side of the island (9). The samples were collected in the first three months of 2002 but probably reflected transmission that had occurred months earlier in 2001. Seropositive bird species included Turdus aurantius $(n=4)$, Myiopagis cotta (2), Coereba flaveola (2), Tiaris bicolor (2), and one each of seven other species. Seropositivity was determined by comparing PRNT $_{90}$ titers for WNV, SLEV and Ilheus virus, a South American flavivirus that is genetically closely related to SLEV, but not in the same antigenic complex as SLEV and WNV (10). All 17 WNVpositive samples were at least four-fold greater in WNV titer than other flavivirus titers. Three samples were positive for SLEV-neutralizing antibodies, which has been previously isolated in Jamaica (11). No samples were positive for Ilheus virus, but five additional samples had similar titers for both SLEV and WNV, and these were classified as undetermined flavivirus infections. The 2001 WNV activity in Jamaica and the Cayman Islands was most likely the result of the same introduction mechanism as postulated for extreme southern Florida: southward dispersal of the virus below limits of detection via migrating birds late in 2000.

Operating under the premise that birds would carry WNV along migration routes, efforts were initiated to detect WNV activity on the southern side 
of the Gulf of Mexico, where millions of neotropical migratory birds make landfall each year and spend the winter months. Beginning in 2000, a joint effort by the Universidad Autónoma de Yucatán and Colorado State University blood-sampled and tested migratory and resident birds in Yucatán State, Mexico. The following year, the Smithsonian Institution also began sampling birds on the Yucatán Peninsula. Further south in the Lacandón Forest of Chiapas State, a joint federal Mexico-United States study evaluated blood from about 200 resident domestic animals sampled in July of 2001. From these, a single seropositive cow (Bos sp.) with a $\mathrm{PRNT}_{90}$ for WNV of 1:80 and a PRNT 90 for SLEV of 1:20, was considered a probable case of WNV infection (12). However, these authors cautioned against concluding that WNV had reached southern Mexico. They reasoned that a major range extension should be confirmed by a second detection of infection. Also, no evidence of WNV transmission had been detected at that time in the nearby Yucatán Peninsula $(9,13)$. The Chiapas study demonstrated serologic evidence for infections due to uncharacterized flaviviruses which could have resulted in cross-reaction with WNV. Secondary flavivirus infections are notorious for causing elevated heterologous flavivirus titers (14).

\section{Spread of West Nile virus 2002-2004}

In 2002, WNV continued to spread in the Caribbean Basin. Guadeloupe (French West Indies) reported numerous subclinical infections in horses and chickens, determined serologically by neutralization (15). In July $2002,10.4 \%$ of the healthy horses in four locations were positive and by January 2003, 61.6\% had become positive in these locations. The absence of reported neurologic disease in these horses is mysterious. Subsequent surveillance in 2003 and 2004 failed to detect any transmission (16).

In the Dominican Republic on the Greater Antillean island of Hispaniola, a University of Kansas study team
FIGURE 1. Countries of Latin America and the Caribbean with reported activity for West Nile virus (in black) between 2001 and 2004, including Mexico, Belize, Guatemala, El Salvador, Cuba, Bahamas, Cayman Islands, Jamaica, Dominican Republic, Puerto Rico (United States), Guadeloupe (French West Indies), Trinidad and Tobago, and Colombia

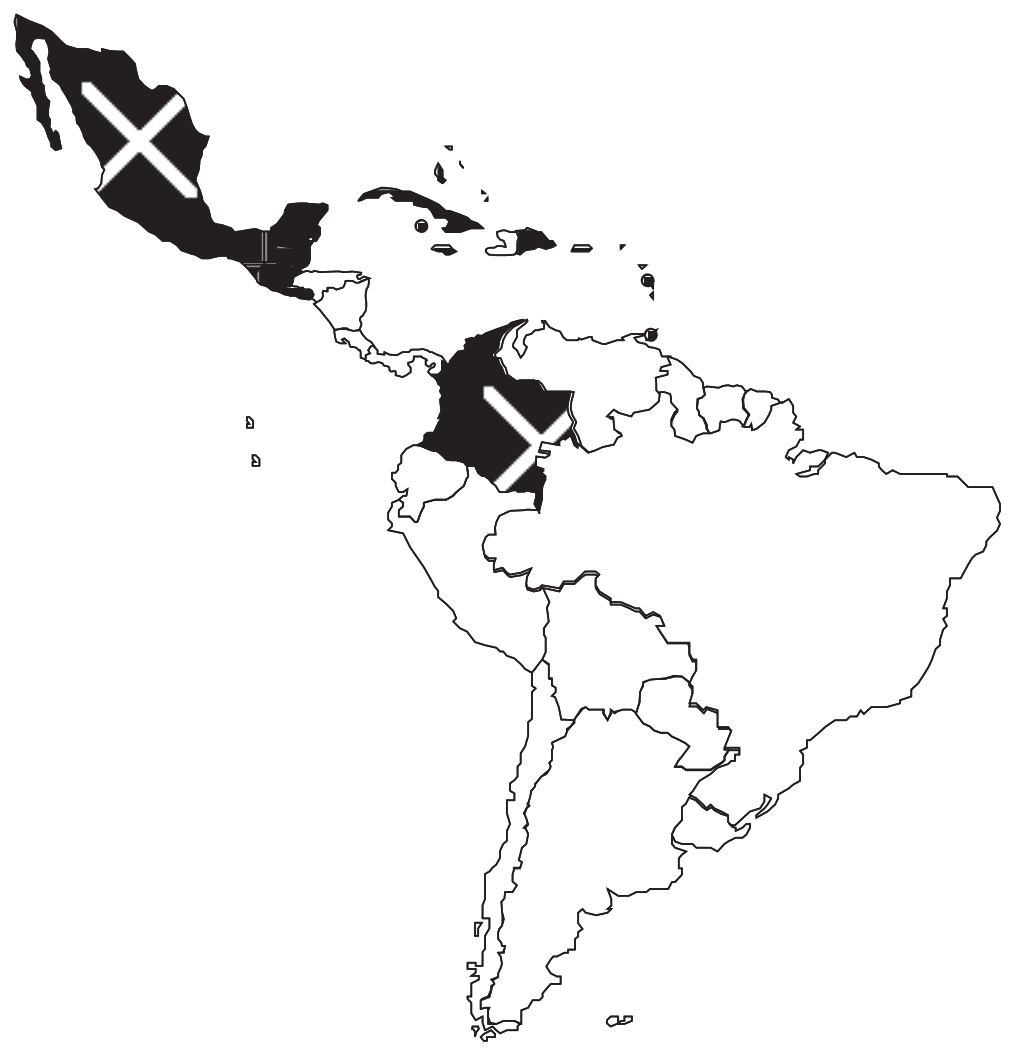

sampled blood and tissues from resident birds captured in November, 2002, for museum collections (17). Five birds of $33(15.2 \%)$ from the Parque Nacional Los Haitises on the northeast coast tested positive for WNV antibodies by neutralization and a specific inhibition-ELISA test. A follow-up study in March, 2003, yielded 12 more WNV-seropositive birds of $58(20.7 \%)$ at the Parque Nacional Monte Cristi in northwest Dominican Republic, along the border with Haiti (18). Positive Dominican bird species included Phaenicophilus palmarum $(n=4)$, two each of Ploceus cucullatus, Saurothera longirostris, Loxigilla violacea and Turdus plumbeus, and one each of five other species.

Evidence of WNV infection was confirmed in Mexico as of July, 2002. Seropositive horses were reported from six states (Chihuahua, Coahuila,
Tamaulipas, Veracruz, Tabasco and Yucatán) (19-21). Seropositive birds were rare and were first detected in the early winter months of $2003(13,22)$.

Mexican authorities began widespread serosurveys in horses and birds in 2003 and found many seropositive horses in 22 states (J. Mendez, personal communication, 4 Feb 2004), with no human cases in 2003 and six human cases (three with encephalitis) in northern Mexico in 2004 (23). The first Mexican isolate came from a dead captive common raven (Corvus corax) in Tabasco State (southeast Mexico) in May, 2003 (21). Additional isolates from dead birds were obtained in northwest Mexico later in 2003 and 2004. Phylogenetic analysis of the prM-E region of the WNV genome isolated from the raven in Tabasco linked it to central United States strains from 2002, but revealed slightly greater genetic variation than previous 
reports for North American WNV strains (21). Two of the 9 nucleotide mutations resulted in amino acid changes, and one of these altered a glycosylation site within the envelope (E) protein. Virulence testing of plaque-purified subcultures of this isolate revealed variants with reduced virulence in mice (24). Similar observations had been made with a Texas 2002 isolate (25).

The widespread WNV seropositivity among horses observed in Mexico in 2003 was also present in the Central American republics of El Salvador and Guatemala (26, M.E. Morales-Betoulle et al., manuscript in preparation). However, anecdotal reports of fatal or life-threatening neurologic disease in Mexican and Central American horses have rarely been confirmed as due to WNV. One encephalitic horse diagnosed with WNV infection was reported from Belize, with onset October 31, 2003. Interestingly, 2000 birds sampled in Belize earlier in 2003 and another 2000 in 2002 all tested negative for WNV antibodies (27).

West Nile virus activity continued in the eastern Caribbean region in 2003. In the Bahamas, a human case of WNND was diagnosed with onset in July, 2003 (28). In early 2004, two seropositive Turdus plumbeus (of 734 birds sampled) were detected in Guantanamo Bay Naval Base at the eastern point of Cuba, and in eastern Puerto Rico, one Coereba flaveola (of 1200 birds sampled) was seropositive, probably reflecting transmission in 2003 (29). Three neutralizing antibody- and IgM-positive, healthy horses were also reported in eastern Puerto Rico in May, 2004, and two others were found in central Puerto Rico in July, 2004 (A. Diaz et al., manuscript in preparation). Mosquitoes collected from the locations where seropositive horses resided tested negative for WNV infection. Four seropositive horses from the Havana region and three human WNND cases in central Cuba were announced in January, 2005 (G. Kouri, personal communication, 2 February 2005), reflecting transmission in 2004.

In the fall of 2004,8 resident unvaccinated horses (of 200 sampled) and 2 domestic Muscovy ducks (of 40 resi- dent birds sampled) were seropositive for WNV in Trinidad (28; R. Salas, personal communication, 17 November 2005), and 12 seropositive equines (of 130 sampled) were reported in northern Colombia (30). These reports mark the first evidence of WNV activity in South American ecosystems (the island of Trinidad is located within sight of the South American mainland off the coast of Venezuela). Efforts to detect WNV-specific antibodies in resident and migrant birds in Brazil in 2002 and 2003 were unsuccessful (31). With the incursion of WNV into northern South America in 2004, it becomes the only zoonotic flavivirus to have been identified in six continents.

\section{DISCUSSION}

The failure of efforts to isolate the virus or detect genomic RNA from WNV in Latin America and the Caribbean (with a few exceptions in Mexico) is perplexing and underscores the concern that serologic evidence for WNV activity is at best indirect. Flaviviruses are notorious for their close antigenic relationships and serologic cross-reactivity (10). In spite of strong serologic evidence from cross-neutralization testing against known flaviviruses from the region, the possibility of misdiagnosis due to cross-reaction with an as yet unrecognized "WN-like" virus still exists. In fact, some of the serologic results classified as due to "undifferentiated flavivirus infection" can best be explained by the existence of such a virus. The recent discovery of two strains of WN-like virus in central Europe lends credence to this concern (32). These two WN-like viruses were both identified serologically as WNV, but genetically they are equidistant from both currently recognized WNV lineages and each other and may represent newly discovered WNV lineages or new WN-like flaviviruses.

Another concern is the strong emphasis placed by several research groups on serologic surveillance of migratory birds $(9,13,22,29,31)$. These studies consume large quantities of valuable resources, yet are unlikely to provide significant results. Given the recent intense transmission of WNV during the summers in temperate North America, the capture of WNseropositive avian survivors either during migration or on the wintering grounds is to be expected because many of these birds normally migrate to neotropical winter territories where they probably continue to circulate antibodies derived from a WNV infection acquired on their North American breeding grounds. Some studies claim that seropositive migrants are evidence that birds could carry WNV long distances. Unfortunately, although plausible, this conclusion is not valid for two reasons. First, the possibility that WNseropositive migratory birds were in fact infected locally cannot be disproved. Second, long-distance migration by a healthy, antibody-circulating bird does not indicate that a viremic bird could make the same longdistance flight. More data are needed to support such a hypothesis. However, the observation of infectious WNV at high titers in tissues of convalescent migratory birds (e.g., Killdeer, Charadrius vociferus) more than one week post-infection and the demonstration of oral infection in raptors would suggest that recently infected birds that recover from viremia, migrate, and then fall prey to a raptor may still introduce WNV into new distant ecosystems if the raptor becomes infected and circulates sufficient virus in its blood to infect mosquitoes (33).

The most pressing concern regarding the reports of WNV in Latin America and the Caribbean is the absence of data on the disease burden in people, horses or birds. Widespread resistance to virulent strains of $\mathrm{WNV}$ in Latin American and Caribbean vertebrates (including people) seems highly unlikely. However, the selection of resistant WNV strains is plausible. If migrating birds are indeed the major mechanism for southward dispersal of WNV, then one could imagine a scenario in which birds infected with highly virulent strains become too sick to migrate, while birds infected with avirulent strains make the long flights 
across seas and deserts successfully, spreading avirulent WNV to new transmission foci along their migratory routes. More research is needed to evaluate this hypothesis, but if proven, this bodes well for the future of WNV epidemics in North America, as the avirulent strain might be reintroduced continually from the south by returning migratory birds. South American arboviruses have in fact been isolated from northward-bound birds during the spring migration in Louisiana (34). This scenario may also explain the apparent low virulence for SLEV in birds and horses in North and South America. In fact, South American strains of SLEV are also less viremogenic in birds than are North American strains, and less virulent in mice (35). Whether an avirulent bird and horse strain of WNV will also be less virulent for humans remains to be seen.

Saint Louis encephalitis virus may be responsible for considerable crossreaction to $\mathrm{WNV}$ in serologic tests of serum from Latin America. The virus is expected to cross-react in about 5\% of primary WNV infections of birds (36). However, in secondary infections, the proportion of samples that cross-react by PRNT is probably much

1. Kost Nile virus: epidemiology and ecology in North America. Adv Vir Res. 2003; 61:185-234.

2. Blackmore CG, Stark LM, Jeter WC, Oliveri RL, Brooks RG, Conti LA, et al. Surveillance results from the first West Nile virus transmission season in Florida, 2001. Am J Trop Med Hyg. 2003;69(2):141-50.

3. Rutledge CR, Day JF, Lord CC, Stark LM, Tabachnick WJ. West Nile virus infection rates in Culex nigripalpus (Diptera: Culicidae) do not reflect transmission rates in Florida. J Med Entomol. 2003;40(3):253-8.

4. Godsey MS Jr, Blackmore M, Panella NA, Burkhalter K, Gottfried K, Halsey L, et al. West Nile virus epizootiology in the southeastern United States, 2001. Vector-Borne Zoonotic Dis. 2005;5(1):82-9.

5. Hribar LJ, Vlach JJ, Demay DJ, Stark LM, Stoner RL, Godsey MS, et al. Mosquitoes infected with West Nile virus in the Florida Keys, Monroe County, Florida, USA. J Med Entomol. 2003;40(3):361-3.

6. Hribar LJ, Stark LM, Stoner RL, Demay DJ, Nordholt AL, Hemmen MJ, et al. Isolation of greater. Secondary flavivirus infections may explain the high rate of flavivirus antibody-positive serum samples in the Caribbean Basin countries that cannot be assigned to a specific infection (because of the presence of similar titers for multiple flaviviruses). Although rarely associated with disease in Latin America, SLEV infections are commonly reported. For example, in Chiapas, Mexico, 20 (10\%) of 196 domestic animals (including three of five horses) were diagnosed as positive for SLEV-neutralizing antibodies by PRNT (12). The known range of distribution for SLEV was expanded through the efforts to detect WNV in the Caribbean Basin. For example, two SLE-seropositive birds reported in Puerto Rico provide the first evidence of SLEV activity from that Caribbean location $(9,29)$.

\section{CONCLUSION AND RECOMMENDATIONS}

Although WNV has yet to present a serious disease threat in Latin America and the Caribbean Basin, an outbreak may be pending. The first major outbreak (with $>100$ human cases of

\section{REFERENCES}

West Nile virus from mosquitoes (Diptera: Culicidae) in the Florida Keys, Monroe County, Florida. Carib J Sci. 2004;40(3):362-7.

7. Marfin AA, Petersen LR, Eidson M, Miller J, Hadler J, Farello C, et al. Widespread West Nile virus activity, eastern United States, 2000. Emerg Infect Dis. 2001;7(4):730-5.

8. Centers for Disease Control and Prevention. West Nile virus activity-United States, 2001. MMWR Morb Mortal Weekly Rep. 2002; 51(23):497-501.

9. Dupuis, AP II, Marra, PP, Kramer, LD. Serologic evidence of West Nile virus transmission, Jamaica, West Indies. Emerg Infect Dis. 2003;9(7):860-3.

10. Calisher $\mathrm{CH}$, Karabatsos N, Dalrymple JM, Shope RE, Porterfield JS, Westaway EG, et al. Antigenic relationships between flaviviruses as determined by cross-neutralization tests with polyclonal antisera. J Gen Virol. 1989; 70(Pt. 1):37-43.

11. Belle EA, King SD, Griffiths BB, Grant LS. Epidemiological investigation for arboviruses in Jamaica, West Indies. Am J Trop Med Hyg. 1980;29(4):667-75.
WNND) in the United States was delayed until 2002, three years after initial detection of the virus in 1999. Public health and veterinary authorities in Latin America and the Caribbean should remain vigilant for unusual clusters of severe disease cases. Dead birds (especially corvids) have been particularly useful for the early detection of WNV activity in North America (37). Corvids are less abundant in Latin America, and thus avian mortality may be less useful as a surveillance technique in this region (38). In countries where WNV has already been detected, surveillance efforts should be expanded. Surveillance guidelines for Latin American and Caribbean Basin countries are available $(28,39,40)$.

Acknowledgments. We thank the numerous public and veterinary health workers throughout Latin America and the Caribbean and their colleagues in North America and Europe who have worked hard to investigate the status of West Nile virus in tropical America. In particular, we thank Gustavo Kouri, Jorge Mendez, Rosa Alba Salas, Maria Eugenia Morales-Betoulle and Annette Diaz for sharing unpublished data.
12. Ulloa A, Langevin SA, Mendez-Sanchez JD, Arredondo-Jimenez JI, Raetz JL, Powers AM, et al. Serologic Survey of Domestic Animals for Zoonotic Arbovirus Infections in the Lacandón Forest Region of Chiapas, Mexico. Vector Borne Zoonotic Dis. 2003;3(1):3-9.

13. Farfán-Ale JA, Blitvich BJ, Lorono-Pino MA, Marlenee NL, Rosado-Paredes EP, GarciaRejon JE, et al. Longitudinal studies of West Nile virus infection in avians, Yucatán State, México. Vector Borne Zoonotic Dis. 2004;4(1): 3-14.

14. Inouye S, Matsuno S, Tsurukubo Y. 'Original antigenic $\sin ^{\prime}$ phenomenon in experimental flavivirus infections of guinea pigs: studies by enzyme-linked immunosorbent assay. Microbiol Immunol. 1984;28(5):569-74.

15. Quirin R, Salas M, Zientara S, Zeller H, Labie J, Murri S, et al. West Nile virus, Guadeloupe. Emerg Infect Dis. 2004;10(4):706-8.

16. Lefrancois T, et al. West Nile virus Surveillance, Guadeloupe, 2003-2004. Emerg Infect Dis. 2005;11(7):1100-3.

17. Komar O, Robbins MB, Klenk K, Blitvich BJ, Marlenee NL, Burkhalter KL, et al. West Nile 
virus transmission in resident birds, Dominican Republic. Emerg Infect Dis. 2003;9(10): 1299-302.

18. Komar O, Robbins MB, Guzman Contreras G, Benz BW, Klenk K, Blitvich BJ, et al. West Nile virus survey of birds and mosquitoes in the Dominican Republic. Vector-borne Zoonotic Dis. 2005;5(2):120-6.

19. Blitvich BJ, Fernandez-Salas I, ContrerasCordero JF, Marlenee NL, Gonzalez-Rojas JI, Komar N, et al. Serologic evidence of West Nile virus infection in horses, Coahuila State, Mexico. Emerg Infect Dis. 2003;9(7):853-6.

20. Loroño-Pino MA, Blitvich BJ, Farfán-Ale JA, Puerto FI, Blanco JM, Marlenee NL, et al. Serologic evidence of West Nile virus infection in horses, Yucatan State, Mexico. Emerg Infect Dis. 2003;9(7):857-9.

21. Estrada-Franco JG, Navarro-Lopez R, Beasley DW, Coffey L, Carrara AS, Travassos da Rosa A, et al. West Nile virus in Mexico: evidence of widespread circulation since July 2002. Emerg Infect Dis. 2003;9(12):1604-7.

22. Fernandez-Salas I, Contreras-Cordero JF, Blitvich BJ, Gonzalez-Rojas JI, CavazosAlvarez A, Marlenee NL, et al. Serologic evidence of West Nile Virus infection in birds, Tamaulipas State, México. Vector Borne Zoonotic Dis. 2003;3(4):209-13.

23. Ramos C, Falcon Lezama JA. 2004. La fiebre del Nilo occidental: una enfermedad emergente en México. Salud Publica Mex. 2004; 46(5):488-90.

24. Beasley DW, Davis CT, Estrada-Franco J, Navarro-Lopez R, Campomanes-Cortes A, Tesh RB, et al. Genome sequence and attenuating mutations in West Nile virus isolate from Mexico. Emerg Infect Dis. 2004;10(12): 2221-4.

25. Davis CT, Beasley DW, Guzman H, Siirin M, Parsons RE, Tesh RB, Barrett AD. Emergence of attenuated West Nile virus variants in Texas, 2003. Virology. 2004;330(1):342-50.
26. Cruz L, Cardenas VM, Abarca M, Rodriguez $\mathrm{T}$, Reyna RF, Serpas MV, et al. Serological evidence of West Nile virus activity in El Salvador. Am J Trop Med Hyg. 2005;72(5):612-5.

27. World Organisation for Animal Health (OIE). West Nile fever in Belize in October 2003. Disease Information 2004;17(10):5 March 2004. Available from: http://www.oie.int/eng/ info/hebdo/AIS 55.HTM\#Sec5. Accessed 3 February 2005.

28. Caribbean Epidemiology Center (CAREC). Recommendations for West Nile virus surveillance in the Caribbean 2004. Available from: http://www.carec.org/west-nile-2004/. Accessed16 March 2005.

29. Dupuis II AP, Marra PP, Reitsma R, Jones MJ, Louie KL, Kramer LD. Serologic evidence for West Nile virus transmission in Puerto Rico and Cuba. Am J Trop Med Hyg. 2005;73(2): 474-6.

30. Mattar Velilla S, Edwards E, Laguado J, González M, Alvarez J, Komar N. West Nile virus infection in Colombian horses. Emerg Infect Dis. 2005;11(9):1497-8.

31. Alves Araújo FA, Teixeira Vianna RS, Vieira de Andrade Filho G, Lemos Melhado D, Todeschini B, Cavalcanti e Cavalcante G, et al. Segundo inquérito sorológico em aves migratórias e residentes do Parque Nacional da Lagoa do Peixe/RS para detecção do vírus do Nilo Occidental e outros vírus. SVS Boletim Electronico Epidemiol. 2004;4(5):1-8.

32. Bakonyi T, Hubalek Z, Rudolf I, Nowotny N Novel flavivirus or new lineage of West Nile virus, central Europe. Emerg Infect Dis. 2005; 11(2):225-31.

33. Komar N, Langevin S, Hinten S, Nemeth N, Edwards E, Hettler D, et al. Experimental infection of North American birds with the New York 1999 strain of West Nile virus. Emerg Infect Dis. 2003:9(3):311-22.

34. Calisher $\mathrm{CH}$, Maness KS, Lord RD, Coleman $\mathrm{PH}$. Identification of two South American strains of eastern equine encephalomyelitis virus from migrant birds captured on the Mississippi delta. Am J Epidemiol. 1971;94(2): 172-8.

35. Bowen GS, Monath TP, Kemp GE, Kerschner JH, Kirk LJ. Geographic variation among St. Louis encephalitis virus strains in the viremic responses of avian hosts. Am J Trop Med Hyg. 1980;29(6):1411-9.

36. Komar N, Panella NA, Burns JE, Dusza SW, Mascarenhas TM, Talbot TO. Serologic evidence for West Nile virus infection in birds in the New York City vicinity during an outbreak in 1999. Emerg Infectious Dis. 2001;7(4): 621-5.

37. Komar N. West Nile virus surveillance using sentinel birds. Annals NY Acad Sci. 2001;951: 58-73.

38. Peterson, AT, Komar N, Komar O, NavarroSiguenza A, Robbins MB, Martinez-Meyer E. West Nile virus in the New World: Potential impacts on bird species. Bird Conservation International. 2004;14(4):215-32.

39. Pan American Health Organization (PAHO). Guidelines for Surveillance, Prevention and Control of West Nile Virus. Epidemiological Bulletin 23(4):December 2002. Available from: http://www.paho.org/english/dd/ais/be v23n4-West_Nile.htm. Accessed 16 March 2005.

40. Mexico, Secretaría de Salud. Guía para la vigilancia, prevención y control del virus del oeste del Nilo. Available from: http://www. cenave.gob.mx/von/default.asp?id=30. Accessed 16 March 2005.

Manuscript received on 28 June 2005. Revised version accepted for publication on 9 December 2005

RESUMEN Objetivos. El virus del Nilo occidental (VNO, familia Flaviviridae, género Flavivirus) se ha propagado rápidamente por toda la cuenca del Caribe desde que se detectó por primera vez en 2001. En este informe se resumen nuestros conocimientos actuales acerca de la transmisión del VNO en zonas tropicales del continente americano.

\section{La actividad del virus del Nilo occidental en América Latina y el Caribe}

Métodos. Revisamos todo lo que se ha publicado sobre el tema y consultamos a autoridades de salud clave para obtener datos inéditos.

Resultados. Las infecciones por el virus del Nilo occidental aparecieron por primera vez en seres humanos residentes de las Islas Caimán y de los Cayos de la Florida en 2001, y en pájaros de aspecto sano de los cuales se obtuvieron muestras a principios de 2002. En 2002 se encontraron pruebas serológicas de infección por el VNO en caballos, pollos y aves de corral no estabuladas oriundas de Guadalupe, la República Dominicana y la parte oriental de México. En 2003, el VNO se diseminó dentro de México y por la parte norte de Centroamérica y se encontraron pruebas serológicas en las Bahamas, Puerto Rico y Cuba. En 2004, las primeras pruebas serológicas de actividad vírica en ecosistemas sudamericanos se detectaron en septiembre y octubre en Colombia y Trinidad, donde se observaron anticuerpos neutralizantes contra el VNO en animales domésticos. Conclusiones. Estos informes esporádicos de enfermedad equina, humana y aviar en América Latina y el Caribe son desconcertantes. Es necesario aislar las cepas para determinar si la atenuación del virus u otro factor explica la carga de enfermedad reducida en ecosistemas tropicales.

Palabras clave Virus del Nilo occidental, América Latina, región del Caribe, arbovirus, vigilancia de la población, flavivirus. 